\title{
Correction to: Behavior and physiological status of pond-cultured pikeperch (Sander lucioperca) broodstock effected by sexual interactions throughout semi-artificial reproduction
}

Oleksandr Malinovskyi ${ }^{1}$ (D) - Jitka Kolářová ${ }^{1}$ • Miroslav Blecha ${ }^{1}$ • Alžběta Stará ${ }^{1}$. Josef Velíšek ${ }^{1} \cdot$ Jiří Křištáan $^{1} \cdot$ Tomáš Policar $^{1}$

Published online: 25 June 2019

(C) Springer Nature Switzerland AG 2019

\section{Correction to: Aquaculture International https://doi.org/10.1007/s10499-019-00401-6}

The original article unfortunately contains interchanged first and family name of the authors.

The corrected names are presented above.

The original article has been corrected.

Publisher's note Springer Nature remains neutral with regard to jurisdictional claims in published maps and institutional affiliations.

The online version of the original article can be found at https://oi.org/10.1007/s10499-019-00401-6

Oleksandr Malinovskyi

omalinovskyi@frov.jcu.cz

1 Faculty of Fisheries and Protection of Waters, South Bohemian Research Centre of Aquaculture and Biodiversity of Hydrocenoses, University of South Bohemia in České Budějovice, Zatisi 728, 389 25 Vodňany, Czech Republic 